\title{
Electronic Waste (E-Waste) Management in India: A Review
}

\author{
Dr. Kousar Jahan Ara Begum \\ Prof. \& Principal, BES College, IV Block, Jayanagar, Bangalore - 560011
}

\begin{abstract}
Introduction: Electronic waste, e-waste, e-scrap, or waste Electrical and Electronic Equipment (WEEE) describes discarded electrical devices. There is a lack of consensus as to whether the term should apply to resale, reuse, and refurbishing industries, or only to product that cannot be used for its intended purpose. Informal processing of electronic waste in developing countries may cause serious health and pollution problems, though these countries are also most likely to reuse and repair electronics. Some electronic scrap components, Such as CRTs (Cathode Ray Tubes), may contain contaminants such as lead, cadmium, beryllium, or brominated flame retardants. Even in developed countries recycling and disposal of e-waste may involve significant risk to workers and communities and great care must be taken to avoid unsafe exposure in recycling operations and leaching of material such as heavy metals from landfills and incinerator ashes. Scrap industry and USA EPA (United States Environmental Protection Agency) officials agree that materials should be managed with caution, but many believe that environmental dangers of used electronics have been exaggerated.
\end{abstract}

\section{WHAT IS E-WASTE?}

Rapid changes in technology, changes in media (tapes, software, MP3), falling prices, and planned obsolescence have resulted in a fast-growing surplus of electronic waste around the globe.

An estimated 50 million tons of E-waste are produced each year in the world. The USA discards 30 million computers each year and 100 million phones are disposed of in Europe each year. The Environmental Protection Agency estimates that only $15-20 \%$ of e-waste is recycled, the rest of these electronics go directly into landfills and incinerators. EPA estimates for 2006-7.

\section{E-Waste Composition:}

The various parts / materials / composition of e-waste may be divided broadly into six categories such as Iron and steel, used for casings and frames

- $\quad$ Non-ferrous metals, especially copper used in cables, and aluminium

- $\quad$ Glass used for screens, windows

- $\quad$ Plastic used as casing, in cables and for circuit boards

- Electronic components

- Others (rubber, wood, ceramic etc.).

\section{E-Waste Scenario in India:}

The Indian information technology industry has a prominent global presence today largely due to the software sector. More recently, policy changes have led to a tremendous influx of leading multinational companies into India to set up manufacturing facilities, $R \& D$ centres and software development facilities. The domestic market is getting revitalized due to buoyant economic growth and changing consumption patterns.

This growth has significant economic and social impacts. The increase of electronic products, consumption rates and higher obsolescence rate leads to higher generation of electronic waste (e-waste). The increasing obsolescence rates of electronic products added to the huge import of junk electronics from abroad create complex scenario for solid waste management in India.

\section{E-waste recycling firm started formally first in Karnataka.}

Parthasarathy's ISO 14001 model, developed with help from Germany's GTZ and Switzerland's EMPA uses a simple, indigenous method that manually dismantles goods like computers, printers, cartridges and other peripherals, segregates and pulverizes, all in an environmentally benign manner. "Less than five percent of waste generated reaches the organized recycling sector", says P. Parthasarathy director of India's first e-recycling firm, the Bangalore-based E-Parisara.

E-Parisara's 50-odd customers are all major corporate, including IBM, Lucent-Alcatel, Hewlett Packard, Intel, Infosys and Motorola. 


\section{Definitions}

"Electronic Waste" may be defined as discarded computers, office electronic equipment, entertainment device electronics, mobile phones, television sets and refrigerators. This definition includes used electronics which are destined for reuse, resale, salvage, recycling, or disposal. Others define the re-usable (working and repairable electronics) and secondary scrap (copper, steel, plastic, etc.) to be "commodities", and reserve the term "waste" for residue or material which is dumped by the buyer rather than recycled, including residue from reuse and recycling operations. Because loads of surplus electronics are frequently commingled (good, recyclable, and non-recyclable), several public policy advocates apply the term "e-waste" broadly to all surplus electronics. Cathode Ray Tubes (CRT) are considered one of the hardest types to recycle. CRTs have relatively high concentration of lead and phosphors (not phosphorus), both of which are necessary for the display. The United States Environmental Protection Agency (EPA) includes discarded CRT monitors in its category of "hazardous household waste" but considers CRTs that have been set aside for testing to be commodities if they are not discarded, speculatively accumulated, or let unprotected from weather and other damage.

Debate continues over the distinction between "commodity" and "waste" electronics definitions. Some exporters are accused of deliberately leaving difficult-to-recycle, obsolete, or non-repairable equipment mixed in loads of working equipment (though this may also come through ignorance, or to avoid more costly treatment processes).

\section{Components / Parts of Computer:}

The various components / parts of computers are as follows.

Mother Board, SMPS (Switch Mode Power Supply), RAM (Random Access Memory), Hard Disk, Processors, Capacitors, IC's (Integrated Circuits), Main Board, Magnetic Touching Sheet, CD Drive, Floppy Drive and Diodes etc..

Components / Parts of Television: The various components / parts of televisions are as follows.

Capacitors, Resistors, Transformers, STR(Supply Transformer Regulator), Integrated Circuits (IC's), LOT(Line output Transformer), Tuners, Condensers, CPT Socket (Colour Picture Tube), Zenor Diode and Normal Diode etc.

\section{Components / Parts of Mobile Phone:}

The various components / parts of mobile phones are as follows.

Lens, internal antenna, aerial, speakers, earpiece, microphone, microphone connectors, loud speakers, buzzers, ringers, charging blocks, system connectors, chassis, slide mechanism, ribbon cables, sim slot covers, readers, backup, battery, battery clip, covers, battery contacts, connectors and kea pad membrane etc.

\section{E-Waste Composition:}

The various parts / materials / composition of e-waste may be divided broadly into six categories such as Iron and steel, used for casings and frames

- $\quad$ Non-ferrous metals, especially copper used in cables, and aluminium

- $\quad$ Glass used for screens, windows

- $\quad$ Plastic used as casing, in cables and for circuit boards

- $\quad$ Electronic components

- $\quad$ Others (rubber, wood, ceramic etc.).

\section{Hazardous Substances in E- Waste -Environmental and Health Effects:}

E-waste is much more hazardous than many other municipal wastes because electronic gadgets contain thousands of components made of deadly chemicals and metals like lead, cadmium, chromium, mercury, polyvinyl chlorides (PVC), brominated flame retardants, beryllium, antimony and phthalates. Long-term exposure to these substances damages the nervous systems, kidney, bones, reproductive and endocrine systems. Some of them are carcinogenic and neurotoxic. A study conducted by Greenpeace in 2005 in electronic recycling yards in Delhi clearly indicates the presence of high levels of hazardous chemicals including dioxins and furans in the areas where this primitive / unauthorized recycling takes place. Disposal of e-wastes is a critical problem faced and poses a threat to both health and vital components of the ecosystem. There are number of channels through which e-waste goes to the environment. E-waste that is land filled produces contaminated leachates, which eventually pollute the groundwater. Acids and sludge obtained from melting computer chips, if disposed on the ground causes acidification of soil, leading to contamination of water resources. Incineration of e-wastes can emit toxic fumes and gases, thereby polluting the surrounding air. Improper recycling and recovery methods can have major impacts on the environment. Crude forms of dismantling can often lead to toxic emissions, which pollute the air and there by also expose the workers to the harmful materials. The most dangerous form of recycling and recovery from e-waste is the open air burning of 
circuit boards (made of plastic) in order to recover copper and other metals. Extraction of metals through acid bath method or through mercury amalgamation also contributes to environmental degradation.

The toxic materials present in the equipments can be environmental as well as health hazard. Mercury will leach when certain electronic devices, such as circuit breakers are destroyed. Not only does the leaching of mercury poses problems, the vaporization of metallic mercury and dimethylene mercury is also of concern. The same is true for polychlorinated biphenyls (PCBs) from condensers. When brominated flame retardant plastic or cadmium containing plastics are land filled, both polybrominated diphenyl ethers (PBDE) and cadmium may leach into the soil and groundwater. It has been found that significant amounts of lead are dissolved from broken lead containing glass, such as the cone glass of cathode ray tubes, gets mixed with acid waters and are a common occurrence in landfills. The rapid growth and faster change in modules of computers, cell phones and consumer electronics becomes major issue that enhances the amount of e-waste generation. Hazardous substances their occurrences and impact on environment and human health is as follows.

Table No. 1.1

Hazardous Substances, their Occurrences and Impacts on Environment and Human Health

\begin{tabular}{|c|c|c|}
\hline Substance & Occurrence in e-waste & Environmental and Health relevance \\
\hline $\begin{array}{l}\text { PCB (polychlorinated } \\
\text { biphenyls) }\end{array}$ & Condensers, transformers & $\begin{array}{l}\text { Cause cancer, effects on the immune } \\
\text { system, reproductive system, nervous } \\
\text { system, endocrine system and other } \\
\text { health effects. Persistent and } \\
\text { bioaccumulataion }\end{array}$ \\
\hline $\begin{array}{l}\text { TBBA (tetrabromo- } \\
\text { bisphenol-A) } \bullet \text { PBB } \\
\text { (polybrominated } \\
\text { biphenyls) } \bullet \text { PBDE } \\
\text { (polybrominated } \\
\text { diphenyl ethers) }\end{array}$ & $\begin{array}{l}\text { fire retardants for plastics } \\
\text { (thermoplastic components, cable } \\
\text { insulation) TBBA is presently the } \\
\text { most widely used flame retardant in } \\
\text { printed wiring boards and covers for } \\
\text { components }\end{array}$ & $\begin{array}{l}\text { can cause long-term period injuries to } \\
\text { health acutely poisonous when burned }\end{array}$ \\
\hline $\begin{array}{l}\text { Chlorofluorocarbon } \\
\text { (CFC) }\end{array}$ & Cooling unit, insulation foam & $\begin{array}{l}\text { Combustion of halogenated substances } \\
\text { may cause toxic emissions. }\end{array}$ \\
\hline $\begin{array}{l}\text { PVC (polyvinyl } \\
\text { chloride) }\end{array}$ & cable insulation & $\begin{array}{l}\text { High temperature processing of cables } \\
\text { may release chlorine, which is } \\
\text { converted } \\
\text { to dioxins and furans. }\end{array}$ \\
\hline Arsenic & $\begin{array}{l}\text { small quantities in the form of } \\
\text { gallium arsenide within light } \\
\text { emitting diodes }\end{array}$ & $\begin{array}{l}\text { acutely poisonous and on a long-term } \\
\text { perspective injurious to health }\end{array}$ \\
\hline Barium & Getters in CRT & $\begin{array}{lll}\text { may develop explosive } & \text { gases } \\
\text { (hydrogen) } & & \\
\text { if wetted } & & \\
\end{array}$ \\
\hline Beryllium & $\begin{array}{l}\text { power supply boxes which contain } \\
\text { silicon controlled rectifiers, } \\
\text { beamline components }\end{array}$ & Harmful if inhaled \\
\hline Cadmium & $\begin{array}{l}\text { rechargeable NiCd-batteries, } \\
\text { fluorescent layer (CRTscreens), } \\
\text { printer inks and toners . }\end{array}$ & $\begin{array}{l}\text { acutely poisonous and injurious to } \\
\text { health } \\
\text { on a long-term perspective }\end{array}$ \\
\hline Chromium VI & data tapes, floppy-disks & $\begin{array}{l}\text { acutely poisonous and injurious to } \\
\text { health } \\
\text { on a long-term perspective causes } \\
\text { allergic reactions }\end{array}$ \\
\hline Gallium arsenide & light-emitting diode (LED) & injurious to health \\
\hline Lead & $\begin{array}{l}\text { CRT screens, batteries, printed } \\
\text { wiring boards }\end{array}$ & $\begin{array}{l}\text { causes damage to the nervous system, } \\
\text { circulatory system, kidneys causes } \\
\text { learning disabilities in children }\end{array}$ \\
\hline Lithium & Li-batteries & $\begin{array}{lll}\text { may develop explosive } & \text { gases } \\
\text { (hydrogen) } & & \\
\text { if wetted } & & \\
\end{array}$ \\
\hline Mercury & $\begin{array}{l}\text { is found in the fluorescent lamps } \\
\text { that provide backlighting in LCDs, } \\
\text { in some alkaline batteries and } \\
\text { mercury wetted switches }\end{array}$ & $\begin{array}{l}\text { acutely poisonous and injurious to } \\
\text { health } \\
\text { on a long-term perspective }\end{array}$ \\
\hline Nickel & $\begin{array}{l}\text { rechargeable NiCd-batteries or } \\
\text { NiMHbatteries, electron gun in } \\
\text { CRT }\end{array}$ & may cause allergic reactions \\
\hline Rare earth elements & fluorescent layer (CRT-screen) & Irritates skin and eyes \\
\hline
\end{tabular}


Electronic Waste (E-Waste) Management In India: A Review

\begin{tabular}{|l|l|l|}
\hline (Yttrium, Europium) & & \\
\hline Zinc sulphide & $\begin{array}{l}\text { is used on the interior of a CRT } \\
\text { screen, mixed with rare earth metals }\end{array}$ & toxic when inhaled \\
\hline $\begin{array}{l}\text { Toxic organic } \\
\text { Substances }\end{array}$ & condensers, liquid crystal display & \\
\hline Toner Dust & $\begin{array}{l}\text { toner cartridges for laser printers / } \\
\text { copiers }\end{array}$ & $\begin{array}{l}\text { Health risk when dust is inhaled risk of } \\
\text { explosion }\end{array}$ \\
\hline
\end{tabular}

(Source: Report on Assessment of Electronic Wastes in Mumbai-Pune Area- MPCB, March 2007)

\section{Initiatives in E Waste Management:}

The Secretariat of the Basal Convention (SBC) has taken a number of initiatives in e-waste management. A pilot project on e-waste management in the Asia and the Pacific Region has been supported by SBC in which India is participating. SBC has also facilitated a Mobile Phone Partnership Program (MP3) with public private partnership. The MP3 has evolved guidelines for environmentally sound management and trans boundary movement of mobile phones. GTZ and MAIT carried out two studies on E- Waste Generation, Disposal and Recycling of Electronic Waste in Delhi and also in other parts of India.

The Department of Information Technology has implemented a project on

"Environmental Management in Semiconductor and Printed Circuit Board Industry in India" in association with United Nations Environment Program (UNEP). The electronic production processes were evaluated to explore environmental implications, promote cleaner production technologies and reduction of hazardous substances in the electronic products.

The Central Pollution Control Board (CPCB) with the help of IRG-Systems South Asia Private Limited (IRGSSA) prepared a status report on "Management, Handling and Practices of E Waste Recycling in Delhi" during 2004- 2005. Based on these studies it was realized that guidelines for Environmentally Sound Management (ESM) of E-Waste is very much essential. As a first step towards ESM, guidelines have been published. The Hazardous Waste (Management and Handling) Rules, 1989 and amended in 2000

and 2003. These rules have been notified under Environment (Protection) Act, 1986 which talk about e-waste also.The Hazardous Waste (Management, Handling and Trans boundary Movement) Rules, 2008 has been notified under Environment (Protection) Act, 1986. This rule also deals with e-waste.

\section{E-Waste Scenario in India:}

The Indian information technology industry has a prominent global presence today largely due to the software sector. More recently, policy changes have led to a tremendous influx of leading multinational companies into India to set up manufacturing facilities, $R \& D$ centres and software development facilities. The domestic market is getting revitalized due to buoyant economic growth and changing consumption patterns.

This growth has significant economic and social impacts. The increase of electronic products, consumption rates and higher obsolescence rate leads to higher generation of electronic waste (e-waste). The increasing obsolescence rates of electronic products added to the huge import of junk electronics from abroad create complex scenario for solid waste management in India.

At the consumer end disposal of e-waste or used product is a big issue. In India computers and peripherals are recycled / reused much more than they are in developed countries. Till the last decade affordability of computers was limited to only a socio- economically advantaged section of the population.

In Indian Scenario, electronics industry has emerged as the fastest growing segment both in terms of production and exports. The share of software services in electronics and IT sector has gone up from 38.7\% in 1998-99 to 61.8\% in 2003-04. A review of the industry statistics show that in 1990-91, hardware accounted for nearly 50\% of total revenues while software's share was $22 \%$. The scenario changed by 1994-95, with hardware share falling to $38 \%$ and software's share rising to $41 \%$. This shift in the IT industry began with liberalization, and the opening up of Indian markets together with which there was a change in India's import policies vis-à-vis hardware leading to substitution of domestically produced hardware by imports. Since the early 1990s, the software industry has been growing at a compound annual growth rate of over $46 \%$ (supply chain management, 1999). Output of computers in value terms, for example, increased by $36.0,19.7$ and $57.6 \%$ in 2000-01, 20022003, and 2003-04, respectively. Within this segment, the IT industry is prime mover with an annual growth rate of $42.4 \%$ between 1995 and 2000. By the end of financial year 2005-06, India had an installed bae of 4.64 million desktops, about 431 thousand notebooks and 89 thousand servers. According to the estimates made by Manufacturers Association of Information Technology (MAIT) the Indian PC industry is growing at a 25\% compounded annual growth rate.

The e-waste inventory based on this obsolescence and rate and installed base in India for the year 2005 has been estimated to be 146180-00 tonnes. This is expected to exceed 8,00,000 tonnes by 2012. There is a lack of authentic and comprehensive data on e-waste availability for domestic generation of e-waste and the various State Pollution Controls Boards have initiated the exercise to collect data on e-waste generation. 
Sixty-five cities in India generate more than $60 \%$ of the total e-waste generated in India. Ten states generate $70 \%$ of the total e-waste generated in India. Maharashtra ranks first followed by Tamil Nadu, Andhra Pradesh, Uttar Pradesh, West Bengal, Delhi, Karnataka, Gujarath, Madya Pradesh and Punjab in the list of e-waste generating states in India. Among top ten cities generating e-waste, Mumbai ranks first followed by Delhi, Bangalore, Chinnai, Kolkata, Ahmedabad, Hyderabad, Pune, Surat and Nagpur. There are two small e-waste dismantling facilities are functioning in Chinnai and Bangalore. There is no large scale organized e-waste recycling facility in India and the entire recycling exists in un-organised sector.

The Indian information technology industry has a prominent global presence today largely due to the software sector. More recently, policy changes have led to a tremendous influx of leading multinational companies into India to set up manufacturing facilities, R\&D centres and software development facilities. The domestic market is getting revitalized due to buoyant economic growth and changing consumption patterns.

This growth has significant economic and social impacts. The increase of electronic products, consumption rates and higher obsolescence rate leads to higher generation of electronic waste (e-waste). The increasing obsolescence rates of electronic products added to the huge import of junk electronics from abroad create complex scenario for solid waste management in India.

At the consumer end disposal of e-waste or used product is a big issue. In India computers and peripherals are recycled / reused much more than they are in developed countries. Till the last decade affordability of computers was limited to only a socio-economically advantaged section of the population. Resale and reuse of computers continues to be high as does dependency on assembled machines. No reliable figures are available as yet to quantify the e-waste generation. Increasingly as computers are becoming more affordable and there is greater access to technology, the turnover of machines could definitely be higher. Apart from the consumer end, another source of more obsolete computers in the market is from the large software industry where use of cutting edge technology, greater computing speed and efficiency necessarily increase the rate of obsolescence. In the same way as the standard of living is growing high / dealers are providing monthly payment/ instalment facilities / banks are providing loans in a comparatively easy way, affordability of televisions, mobile phones and other house hold appliances are enormously increasing. As the consumption pattern increases, e- waste generation also increases. The top ten States and Cities in India generating e- waste are as follows.

Table no. 1.2

The top ten States in India generating e- waste are as follows.

E-Waste / WEEE Generation in Top Ten States

\begin{tabular}{|l|l|l|l|}
\hline S. No. & States & WEEE(Tones) & Percentage \% \\
\hline 1. & Maharashtra & 20270.59 & 18.49 \\
\hline 2. & Tamil Nadu & 13486.24 & 12.30 \\
\hline 3. & Andhra Pradesh & 12780.33 & 11.66 \\
\hline 4. & Uttar Pradesh & 10381.11 & 9.47 \\
\hline 5. & West Bengal & 10059.36 & 9.18 \\
\hline 6. & Delhi & 9729.15 & 8.87 \\
\hline 7. & Karnataka & 9118.74 & 8.32 \\
\hline 8. & Gujarath & 8994.33 & 8.20 \\
\hline 9. & Madhya Pradesh & 7800.62 & 7.11 \\
\hline 10. & Punjab & 6958.46 & 6.35 \\
\hline & Total & 109578.93 & 100 \\
\hline
\end{tabular}

Source: EMPTRI

From the above table, it is noted that Andhra Pradesh and Karnataka stands $3^{\text {rd }}$ and $7^{\text {th }}$ respective in the list among the e- waste generators. As regards to the cities, Bangalore is 2nd and Hyderabad is 5 th in generation of e- waste. Northern India is not a leading generator, it happens to be the leading processing center of e-waste in the country. There are three formal recyclers in the South of India (at Chennai, Hyderabad and Bangalore) and one in Western India.

According to Manufacturer's Association for Information Technology (MAIT) report, India in 2007 generated 3,80,000 tones of e-waste from discarded Computers, Televisions and Mobile Phones. This is projected to grow to more than $8,00,000$ tones by 2012 with a growth rate of $15 \%$. The estimate includes 50 , 000 tones of such e-waste imported from developed countries as charity for reuse, which mostly end up in informal recycling yards either immediately or once the re-used product is discarded. This is a conservative and restricted estimate. Complex, ambiguous definitions of second-hand electronic equipment has made it difficult for the customs department to trace, identify and stop the illegal in-flow of e-waste. 
Table no. -1.3

E-Waste/WEEE Generation in Top Ten Cities

\begin{tabular}{|l|l|l|l|}
\hline S.no. & City & WEEE (Tones) & Percentage \\
\hline 1. & Mumbai & 11017.1 & 24.02 \\
\hline 2. & Delhi & 9730.3 & 21.21 \\
\hline 3. & BANGALORE & 4648.4 & 10.13 \\
\hline 4. & Chennai & 4132.2 & 9.00 \\
\hline 5. & Kolkata & 4025.3 & 8.77 \\
\hline 6. & Ahmedabad & 3287.5 & 7.16 \\
\hline 7. & HYDERABAD & 2833.5 & 6.17 \\
\hline 8. & Pune & 2584.2 & 5.63 \\
\hline 9. & Surat & 1836.5 & 4.00 \\
\hline 10. & Nagpur & 1768.9 & 3.85 \\
\hline & Total & 45863.9 & 100 \\
\hline
\end{tabular}

Source: E-Waste Management in India-Consumer voice, April 2009

The authorized e-waste recycling facilities in India capture only 3\% of total e-waste generated, the rest makes its way to informal recycling yards in major cities like Delhi, Mumbai, Hyderabad and Bangalore. This is because businesses sell their discarded equipment to informal recyclers for quick money without realizing the hazardous implications it causes to health and environment. E-waste contains over 1,000 different substances, many of which are toxic, and creates serious pollution upon disposal. Due to the extreme rates of obsolescence, e-waste produces much higher volumes of waste in comparison to other consumer goods. The increasingly rapid evolution of technology combined with rapid product obsolescence has effectively rendered everything disposable due to which e-waste is generated at alarming rates.

\section{Take back Policy in India:}

As regards to the take back policy in India, Apple, Microsoft, Panasonic, PCS, Philips, Sharp, Sony, Sony Ericsson and Toshiba observes take back option at their production plant. Samsung claims to have a take back service but only one collection point for the whole of India, other nine branded companies do not have take back service. Two brands stand out as having the best take back practice in India, HCL and WIPRO. Other brands that do relatively well are Nokia, Acer, Motorola and LGE.

\section{Resale and reuse of computers:}

Resale and reuse of computers continues to be high as does dependency on assembled machines. No reliable figures are available as yet to quantify the e-waste generation. Increasingly as computers are becoming more affordable and there is greater access to technology, the turnover of machines could definitely be higher. Apart from the consumer end, another source of more obsolete computers in the market is from the large software industry where use of cutting edge technology, greater computing speed and efficiency necessarily increase the rate of obsolescence. In the same way as the standard of living is growing high / dealers are providing monthly payment/ instalment facilities / banks are providing loans in a comparatively easy way, affordability of televisions, mobile phones and other house hold appliances are enormously increasing. As the consumption pattern increases, e- waste generation also increases.

\section{What makes e-waste?}

Discarded electronics devices like TVS, PCs, floppies, CDs, batteries, switches, telephones, ACs, cell phones, electronic toys, refrigerators, washing machines, dryers, kitchen utensils and even aircraft parts. Computer account for 25 per cent of e-waste.

\section{Why is it hazardous?}

Unorganized recycling and backyard scrap-trading from close to 100 per cent of total e-waste processing activity. About 25,000 are employed at scrap-yard in Delhi alone where 10,000 to 20,000 tonnes of e-waste is handled every year. There are e-waste scrap yards in Merut, Ferozabad, Chennai, Bangalore and Mumbai.

Here to 1,700 IT companies, Bangalore is fast becoming a dumping ground for electronic waste generated by these firms. The city generates 8,000 tonnes of e-waste annually. The pilot project to manage ewaste without causing ecological damage has been set up with the backing of the State Pollution Control Board, which would like to see the project replicated in other cities of the country as well.

The business model is simple. Most software firms in the city such as IBM, HP, Lucent and Mphasis have agreements with E-Parisaraa to collect their e-waste . E-Parisaraa pays these firms for the e-waste and 
brings it to their processing facilities in Dobbespet, in the outskirts of the city. What makes E-Parisaraa different is that, unlike the backyard handling of e-waste, there is no melting involved in the sorting.

The waste enters the disassembly-line process where it is dismantled and sorted in plastic, rubber and metal sheets. The leftover printed circuit boards (PCBs) and glass items such as tubes go to the next stage where they are then cut into strips and powered.

\section{International Scenario in E-waste}

Globally, WEEE/E-waste are most commonly used terms for electronic waste. At UNEP web site, it is cited that "e-waste is a generic term encompassing various forms of electrical and electronic equipment (EEE) that are old, end-of-life electronic appliances and have ceased to be of any value to their owners". There is no standard definition of WEEE/E-waste. A number of countries have come out with their own definitions, interpretation and usage of the term "E-waste/WEEE". The most widely accepted definition of WEEE/E-waste is as per EU directive, which is followed in member countries of European Union and other countries of Europe. At first WEEE/E-waste definition as per EU directive, which is followed in member countries as per EU directive has been described followed by description of definitions in Cannada, Japan, USA, Basel Convention and OECD.

Table - 1.4

E-Waste Generation International

\begin{tabular}{|l|l|l|l|}
\hline Sl. No. & Country & $\begin{array}{l}\text { Total E-Waste } \\
\text { Generated tones/ } \\
\text { year }\end{array}$ & Year \\
\hline $\mathbf{1 .}$ & Switzerland & $66,042^{*}$ & 2003 \\
\hline $\mathbf{2 .}$ & Germany & $1,100.000$ & 2005 \\
\hline $\mathbf{3 .}$ & United Kingdom & 915,000 & 1998 \\
\hline $\mathbf{4 .}$ & U.S.A & $2,124,400$ & 2000 \\
\hline $\mathbf{5 .}$ & Taiwan & 14,036 & 2003 \\
\hline $\mathbf{6 .}$ & Thailand & 60,000 & 2003 \\
\hline $\mathbf{7 .}$ & Denmark & 118,000 & 1997 \\
\hline $\mathbf{8 .}$ & Cannada & 67,000 & $2008^{*}$ \\
\hline $\mathbf{9 .}$ & India & $8,00,000$ & 2012 \\
\hline
\end{tabular}

Source - From various agencies of the different countries, also see references.

(*) This is the quantity of e-waste generated in Switzerland that is physically weighed

Notes: The table above gives only an overview of the quantities of e-waste generated in different countries. It is difficult to make direct country to country comparisons regarding ewaste quantities, because each country has as different categories of appliances counted in ewaste and different methodologies of estimation.

\section{Basel Convention}

Basel Convention covers all discarded/disposed materials that possess hazardous characteristics as well as all wastes considered hazardous on a national basis. Annex VIII, refers to e-waste, which is considered hazardous under Art. 1, par. 1(a) of the Convention: A1180 Waste electrical and electronic assemblies or scrap containing components such as accumulators and other batteries included on list A, mercuryswitches, glass from cathode-rat tubes and other activated glass and PCB-capacitors, or contaminated with Annex I constituents (e.g., cadmium, mercury, lead, polychlorinated biphenyl) to an extent that they possess any of the characteristics contained in Annex III. Annex IX, contains the mirror entry, B1110 Electrical and Electronic assemblies given below.

- Electronic assemblies consisting only of metals or alloys

- Waste electrical and electronic assemblies or scrap (including printed circuit boards) not containing components such as accumulators and other batteries included on List A, mercury-switches, glass from cathoderay tubes and other activated glass and PCB-capacitors, or not contaminated.

OECD (2001)

WEEE / E-waste have been defined as "any appliance using an electric power supply that has reached its endof-life."

\section{Other Countries \\ European Union (EU)}


Definition as per EU directive has been described below. Countries, which have transposed this definition into their national legislations are Austria, Belgium, Cyprus, Czech Republic, Denmark, Estonia, Finland, France, Germany, Greece, Hungary, Ireland, Italy, Latvia, Lithuania, Luxembourg, The Netherlands, Norway, Poland, Portugal, Slovakia, Slovenia, Spain, Sweden, Switzerland and United Kingdom.

\section{Ontario}

The Waste Electronic and Electrical Equipment (WEEE) regulation under the Waste Diversion Act, 2002 (WDA) was filed on December 14, 2004. The regulation designates seven categories of electronic and electrical equipment as waste, and targets more than 200 items that could be designated, including computers, telephones, broadcast equipment, televisions and CD players, children's toys, power tools, lawn mowers and navigational and medical instruments. Products targeted under Ontario WEEE legislation are given in below.

Table No: 1.5

Products Designated under Ontario Legislation

\begin{tabular}{|c|c|c|}
\hline Priority Categories & List of WEEE Products & \\
\hline Household Appliances & $\begin{array}{ll}- & \text { Air conditioners } \\
\cdot & \text { Clothes dryers } \\
\cdot & \text { Clothes washers } \\
\text { - } & \text { Stove }\end{array}$ & $\begin{array}{ll}\cdot & \text { Dishwashing machines } \\
\text { - } & \text { Freezers } \\
& \text { Refrigerators }\end{array}$ \\
\hline IT Equipment & 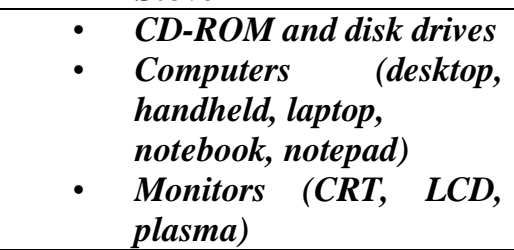 & $\begin{array}{ll}\cdot & \text { PDAs } \\
\cdot & \text { Keyboard, mouse, } \\
\cdot & \text { terminals } \\
\cdot & \text { Printers, copiers, } \\
\text { typewriters }\end{array}$ \\
\hline $\begin{array}{l}\text { Telecommunications } \\
\text { equipment }\end{array}$ & $\begin{array}{l}\text { Fax/telephone answering } \\
\text { machine } \\
\text { Modems }\end{array}$ & $\begin{array}{ll} & \text { Pagers } \\
\cdot & \text { Telephones (cell, } \\
& \text { cordless, wire) }\end{array}$ \\
\hline $\begin{array}{l}\text { Audio-Visual } \\
\text { Equipment }\end{array}$ & $\begin{array}{ll}\cdot & \text { Sound equipment } \\
\cdot & \text { Cameras }\end{array}$ & $\begin{array}{c}\cdot \quad \text { Televisions } \\
\cdot \quad \text { Video player, } \\
\text { projector, recorder }\end{array}$ \\
\hline
\end{tabular}

Source: Ontario Legislation

\section{Saskatchewan}

"The Waste Electronic Equipment Regulations" filed on October 13, 2005 under The Environmental Management and Protection Act, 2002, defines WEEE/ E-waste as "waste electronic equipment", which means electronic equipment that the consumer no longer wants.

"Electronic Equipment" means any electronic equipment listed in Column 1 of Table 1 of these regulations. This table includes following electronic equipment

- Personal desktop computer, including the central processing unit and all other parts

- contained in the computer

- Personal notebook computer, including the central processing unit and all other

- parts contained in the computer

- Computer monitor, including cathode ray tube, liquid crystal display and plasma,

- Computer mouse, including cables

- Computer printer including dot matrix; ink jet; laser; thermal and computer printer

- with scanning or facsimile capabilities or both

- Television (cathode ray tube, liquid crystal display, plasma and rear projection)

Japan

There is no specific definition of WEEE/ E-waste as defined in the regulatory system.

E-waste is covered under laws to promote recycling within Japan. The two major laws covering broad range of E-waste items are "The Law for Recycling of Specified Kinds of Home Appliances (Home Appliances Recycling Law)" enacted in 1998 and "The Law for Promotion of the Effective Utilization of Resources" enacted in 2000. 
In "The Law for Recycling of Specified Kinds of Home Appliances (Home Appliances Recycling Law)", Ewaste is referred as "Used Consumer Electric Goods Discarded by Consumers". This law covers TVs, Refrigerators, Washing Machines and Air Conditioners.

In "The Law for Promotion of the Effective Utilization of Resources", E-waste is covered under "Used goods and by-products" which have been generated and their large part is discarded. This law covers personal computers (home and office) and other electronic items. According to this law "Used goods" means any articles that are collected, used or unused, or is disposed of (except radioactive materials or those contaminated thereby). "By-product" means any articles obtained secondarily in the process of manufacturing, processing, repair or sale of the product; in the process of supply of energy; or in the process of construction pertaining to architecture and civil engineering (hereinafter referred to as "construction work") except radioactive materials or those contaminated thereby.

USA

According to USEPA, Electronic products that are "near" or at the "end of their useful life" are referred to as "e-waste" or "e-scrap." Recyclers prefer the term "e-scrap" since "waste" refers only to what is left after the product has been reused, recovered or recycled. However, "E-waste" is the most commonly used term.

In developed countries, currently, it equals $1 \%$ of total solid waste generation and is expected to grow to $2 \%$ by 2010. In USA, it accounts $1 \%$ to $3 \%$ of the total municipal waste generation. In EU, historically, e-waste is growing three times faster than average annual municipal solid waste generation. A recent source estimates that total amount of e-waste generation in EU ranges from 5 to 7 million tonnes per annum or about 14 to $15 \mathrm{~kg}$ per capita and is expected to grow at a rate of $3 \%$ to $5 \%$ per year. In developing countries, it ranges $0.01 \%$ to $1 \%$ of the total municipal solid waste generation. In China

and India, though annual generation per capita is less than $1 \mathrm{~kg}$, it is growing at an exponential pace.

\section{Significance of the Study}

- Electronic waste or e-waste is one of the rapidly growing environmental problems of the world.

- Rising levels of penetration of computers and communication equipments is irreversible, but unless we handle with skill and determination, it will mean permanent disastrous to the world.

- In India, the electronic waste management assumes greater significance not only due to the generation of our own waste but also dumping of e-waste particularly computer waste from the developed countries.

- With extensively using computers and electronic equipments and people dumping old electronic goods for new ones, the amount of E-waste generated has been steadily increasing.

- All big metropolitan cities, generates sizeable amount of e-waste.

- At present Bangalore alone generates about 8000 tonnes of computer waste annually and in the absence of proper disposal, they find their way to scrap dealers.

After the mid of 2009 one formal authorized recycler by name Earth Sense has established its recycling facility in Hyderabad in collaboration with already existing formal recycler, by name $\mathbf{E}$ - Parisaraa in Bangalore. Although these recyclers do exist but most of the waste finds its way into un authorized recycling centres / scrap dealers etc. for quick money. The workers are

women and children in most of these units. On an enquiry they informed that there is no health problem but a study need to be taken up to find the actual pollution load generated and health problems among the workers.

\section{Important Objectives of Environment \& Forests Central Pollution Control Board: Objective of the Guidelines}

The objective of these Guidelines is to provide guidance for identification of various sources of waste electrical and electronic equipments (e-waste) and prescribed procedures for handling e-waste in an environmentally sound manner.

These Guidelines shall apply to all those who handle e-waste which includes the generators, collectors, transporters, dismantlers, recyclers and stakeholders of e-wastes irrespective of their scale of operation.

In India, there are no specific environmental laws or Guidelines for e-waste. None of the existing environmental laws have any direct reference to electronic waste or refer to its handling as hazardous in nature. However several provisions of these laws may apply to various aspects of electronic wastes. Since e-waste or its constituents fall under the category of "hazardous" and "non-hazardous waste", they shall be covered under the purview of "The HAZARDOUS Waste Management Rules, 2003".

Composition of e-waste is very diverse and differs in products across different categories. Broadly, it consists of ferrous and non-ferrous metals, plastic, glass, wood \& plywood, printed circuit boards, concrete and ceramics, rubber and other items. Iron and steel constitutes about $50 \%$ of the e-waste followed by plastics $(21 \%)$. Non-ferrous metals (13\%) and other constituents. Non-ferrous metals consist of metals like copper, aluminum and precious metals e.g., silver, gold, platinum, palladium etc. The presence of elements like lead 
mercury, arsenic, cadmium, selenium and hexavalent chromium and flame retardants beyond threshold quantities in e-waste classifies them as hazardous waste.

The e-waste inventory based on this obsolescence rate and installed base in India for the year 2005 has been estimated to be 146180.00 tones. This is expected to exceed 8, 00,000 tones by 2012 . There is a lack of authentic and comprehensive data on e-waste availability for domestic generation of e-waste and the various State Pollution Control Boards have initiated the exercise to collect data on e-waste generation.

Sixty-five cities in India generate more than $60 \%$ of the total e-waste generated in India. Ten states generate $70 \%$ of the total e-waste generated in India. Maharashtra ranks first followed by Tamil Nadu, Andhra Pradesh, Uttar Pradesh, West Bengal, Delhi, Karnataka, Gujarat, Madhya Pradesh and Punjab in the list of e-waste generating states in India. Among top ten cities generating e-waste, Mumbai ranks first followed by Delhi, Bangalore, Chennai, Kolkata, Ahmadabad, Hyderabad, Pune, Surat and Nagpur.

All the three levels of e-waste treatment are based on material flow. The material flows from $1^{\text {st }}$ level to $3^{\text {rd }}$ level treatment. Each level treatment consists of unit operations, where e-waste is treated and output of $1^{\text {st }}$ level treatment serves as input to $2^{\text {nd }}$ level treatment. After the third level treatment, the residues are disposed of either in TSDF or incinerated. The efficiency of operations at first and second level determines the quantity of residues going to TSDF or incineration.

The establishment of E-waste Recycling \& Treatment Facility shall be in line with the existing Guidelines/best practices/requirements in India for establishing and operating "Recycling and Treatment and Disposal Facilities" for hazardous wastes. Such facilities shall be set up in the organized sector. However, the activities presently operating in the informal sector need to be upgraded to provide a support system for the integrated facility. This would enable to bring the non-formal sector in the main stream of the activity and facilitate to ensure environmental compliances.

The procedures for setting up \& management of e waste facility shall include licenses from all appropriate governing authorities such as environmental clearance, recycler registration from Central Pollution Control Board under HW Rules, obtaining of consents under water act, Air act and authorization from the state pollution control board.

The Extended Producer Responsibility (EPR) is an environment protection strategy that makes the producer responsible for the entire life cycle of the product, especially for take back, recycle and final disposal of the product. Thus the producers' responsibility is extended to the post-consumer stage of the product life cycle. This needs to be included in the legislative framework making EPR a mandatory activity associated with the production of electronic and electrical equipments over a period of time.

These Guidelines are reference document for the management handling and disposal of e-wastes. These are intended to provide guidance and broad outline, however, the specific methods of treatment and disposal for specific wastes under question. These Guidelines provide the minimum practice required to be followed in the management of e-wastes and State Department of Environment or State Pollution Control Board may prescribe more stringent norms as deemed necessary.

\section{Need for the Guidelines for Environmentally Sound Management}

Based on the outcome of the studies carried out and the consensus arrived at the National Workshop on electronic waste management held in March 2004 and June

2005 organized by CPCB and Ministry of Environment \& Forests an assessment was made of the existing practice in the e-waste management.

\section{REGULATORY REGIME FOR E-WASTE}

In India, there are no specific environmental laws or Guidelines for e-waste.

None of the existing environmental laws have any direct reference to electronic waste or refer to its handling as hazardous in nature. However several provisions of these laws may apply to various aspects of electronic wastes. Since e-waste or its constituents fall under the category of "hazardous" and "non-hazardous waste", they shall be covered under the purview of "The Hazardous Waste Management Rules, 2003".

Given important objectives and guidelines, the important positive achievements of E-waste management and recycling are ---

\section{E-waste recycling firm started formally first in Karnataka.}

Parthasarathy's ISO 14001 model, developed with help from Germany's GTZ and Switzerland's EMPA uses a simple, indigenous method that manually dismantles goods like computers, printers, cartridges and other peripherals, segregates and pulverizes, all in an environmentally benign manner. "Less than five 
percent of waste generated reaches the organized recycling sector", says P. Parthasarathy director of India's first e-recycling firm, the Bangalore-based E-Parisara.

E-Parisara's 50-odd customers are all major corporate, including IBM, Lucent-Alcatel, Hewlett Packard, Intel, Infosys and Motorola.

All players in this field, NGOs, Activists, E-recyclers and agencies are now preparing to go to the Indian government to request a comprehensive, law on e-waste generation, manufacturing, importing and exporting. 3. "The guidelines issued by the central pollution control board earlier this year on e-waste management are not mandatory. We want a separate law," says Parathasarathy

\section{Policy Recommendations}

A major component of the initiative's activities is to provide technical expertise for Informed policy making at various levels. Technical models for the management of e- Waste have been suggested and thoroughly discussed in various fore, allowing for Incorporating the concerns of the different stakeholders. Recently, the initiative has

been involved in suggesting models for the management of e-waste in India through A concept note. The main objective of this concept note is to create a consensus Amongst all the stakeholders in arriving at an acceptable and feasible solution for India. The aim is also to raise issues that stimulate the necessary debate to fine-tune The proposed models, paving the way towards a regulated and organized e-waste Management system in India. The concept note proposes that the various steps in Providing a new direction to WEEE management system in India is as follows: Conceptualizing and defining the necessary building blocks for a proper e- Waste management model in India.

\section{Creating a broad consensus amongst the various stakeholders of WEEE \\ Management system about the viability of the proposed Extended Producer Responsibility (EPR) models. Implementation of the EPR model. \\ Legislation based on regular monitoring and evaluation of the model.}

This concept note focuses on the first step, thereby, proposing the building blocks for An e-waste management system for India. The optimal model for India would only Emerge after necessary deliberations and dialogue over the building blocks and a Broad consensus over the roles and responsibilities of the various stakeholders.

Moreover, the note also suggests that these building blocks would be essential for any Suggested model, be it a Collective Responsibility or an Individual Responsibility Model. The Collective Responsibility Model bestows the management responsibilities Of the entire system on a collective industry body referred to as the Producer Responsibility Organization.

The Individual Responsibility Model, on the other hand, Suggests that individual producers design the optimal management system for the e- Waste generated by their products. Since both models have certain disadvantages, in Addition to their distinct advantages, a combination of the two models might Constitute the optimal model for India. However, as mentioned above, the building Blocks for both the models, discussed in the concept note in detail, remain the same And is the focus of the concept note. One of the key lacunae in the present scenario is the absence of a regulatory Framework for the management of e-waste. A regulatory framework, besides being regulatory, is also enabling if the proper implementation body exists. In the case of e- Waste, a proper regulatory framework would need to enable proper collection and Recycling and to 'set the rules' therein. Clearcut responsibilities and requirements go A long way in ensuring that there is adequate investment by responsible actors on the Ground and not providing that clarity only continues the chaos. Moreover, as stated Above, the legal framework needs to ensure the health and safety standards of the People involved in the operations, along with issues of emissions to the environment And waste emerging from such operations. Several laws already tackle these aspects, Though there are no guidelines explaining how they apply to e-waste. A first crucial Step is to look at these existing laws and define clearly their application to e-waste Recycling. A specific legislation for e-waste can then be formulated to 'fill the gaps' Not covered by existing law. Further, it is essential to not only streamline the existing Set-ups but also attract recyclers who make the recycling process safe and efficient.

Government incentives like providing land, financial subsidies, and so on can go a Long way in ensuring a viable collection and recycling system. Therefore, any Legislation must be in line with right incentives for the involved stakeholders. Keeping the objectives and concerns mentioned above in mind, one of the ultimate Aims of the activities of the initiative is also to stimulate discussion amongst the Various stakeholders for the development of a regulatory framework that is Acceptable to all stakeholders. The initiative was, and is still, involved in drawing up The guidelines for the management and handling of e-waste. A national-level workshop was organized under the initiative to discuss the guidelines. However, at The time, there were no proper guidelines for the management of e- Waste in the country. 


\section{Notes and References:}

[1]. BAN \& SVTC/ with Contributions from Toxics Link, SCOPE and Greenpeace, China. 2002. Exporting Harm- The High Tech Trashing of Asia. (Website http://ban.org/E-waste/technotrashfinalcomp.pdf viewed on 2007/07/15).

[2]. Beary, H., 2005. Bangalore faces e-waste hazards. (Website http://news.bbc.co.uk/2/hi/south_asia/4222521.stm viewed on 2007/07/14).

[3]. E-Waste Guide. (Website http://www.e-waste.in/ viewed on 2007/07/10).

[4]. Global Knowledge Partnership Secretariat. Multistakeholder Partnerships - IssuePapers.(Website 2007/07/21).http://www.fdc.org.au/Files/Information/4.2\%20MSP.pdfviewedon

[5]. Goel, R., 2006. Electronics, Environmental Requirements and Eco-Design: OverviewofdevelopingactivitiesinIndia.(Website htp://www.cfsd.org.uk/aede/english/ Goel

[6]. Greenpeace, 2005. Report on recycling of e-waste in India and China. (Website http://www.greenpeace.org/raw/content/international/press/reports/recycling- of-electronic-waste.pdf viewed on 2007/07/16).

[7]. Hemmati, M. 2001. Multistakeholder processes- a methodological framework. Website http://www.earthsummit2002.org/msp/workshop/minu.html viewed on 2007/07/21).

[8]. Kalam, A.P.J., 2006. Interactive session with top intellectuals of Singapore -dynamicsofeconomicgrowthinIndia.(Website http://meaindia.nic.in/speech/2006/02/02SS05.pdf viewed on 2007/07/17).

[9]. Kara, J. \& Quarless, D., 2002. Guiding principles for partnerships for sustainable development to be elaborated by interested parties in the context of worldsummitonsustainabledevelopment.(Website http://www.iisd.ca/wssd/download\%20files/annex_partnership.pdf viewed on 2007/07/18)

[10]. Keller, M., 2006. Assessment of gold recovery process in Bangalore, India and evaluation of an alternative recycling for printed wire boards (Website http://www.empa.ch/plugin/template/empa/*/59244/---/l=2viewedon 2007/12/18).

[11]. MAIT, 2007. Third quarter PC sales cross 1.39 million units. (Website http://www.mait.com/pressupdate1.jsp?Id=69 viewed on 2007/07/20).

[12]. Newindpress, 2007. Let's tackle this new age trash. (Website http://www.newindpress.com/NewsItems.asp?ID=IE120070606001713 viewed on 2007/07/18).

[13]. Personal Communication. Parthasarthy, P., Director, E-Parisara Pvt. Ltd.

[14]. Raghupathy, L., 2007. E-waste management in India. (Website viewedon http://www.env.go.jp/recycle/3r/en/asia/02_03-4/11.pdf 2007/07/11).

[15]. Satyamurthy, K., 2006. Managing e-waste without harming environment. (Website http://www.hinduonnet.com/thehindu/thscrip/print.pl?file=200604032154040 $\quad 0$. htm\&date $=2006 / 04 / 03 / \& p r d=$ th $\& \quad$ viewed on 2007/07/16).

[16]. Toxics Link, 2003. Scrapping the Hi Tech Myth - computer waste in India. (Website http://www.toxicslink.org/pubview.php?pubnum=37 viewed on 2007/07/15)

[17]. Williams, E., 2005. International activities on E-waste and guidelines for futurework.(Websitehttp://www.itenvironment.org/publications/international\%20ewaste.pdfviewedon 2007/07/10).

[18]. WorldBank,2006.India-CountryOverview, http://www.worldbank.org.in viewed on 2007/07/17). 